\title{
Membrane Lipid Fluidity and Filterability of Red Blood Cells from Adults and Newborns
}

\author{
LYNN M. CRESPO, ELLEN M. BIFANO, AND JEFFREY C. FREEDMAN \\ Departments of Pharmacology, Pediatrics and Physiology, State University of New York Health Science Center at \\ Syracuse, Syracuse, New York 13210
}

\begin{abstract}
Membrane lipid fluidity was reexamined in red blood cells and ghosts from adults and newborns. Fluorescence anisotropies of the hydrophobic probes 1,6diphenyl-1,3,5-hexatriene (DPH) and perylene were significantly and substantially greater in fresh intact red cells from newborns than from adults; however, no significant difference was detected with the polar fluorophores, 12-(9anthroyl) stearic acid and retinol. These results suggest that probes in the hydrophobic core of the membrane have less motional freedom in red cells from newborns than from adults, whereas probe motional freedom in the polar lipid headgroup regions of the membranes is similar for both cell types. DPH fluorescence anisotropy increased upon making white ghosts or upon storage of blood. Temperature studies indicated that DPH fluorescence anisotropy in fresh intact neonatal red cells is increased by an amount corresponding to that produced by cooling adult red cells by $22^{\circ} \mathrm{C}$. Elevated intracellular calcium decreased red cell filterability without affecting DPH fluorescence anisotropy of ghost membranes. This result suggests that the effect of calcium in reducing filterability is independent of alterations in membrane lipid motional freedom. It is unlikely that the decreased lipid motional freedom of red cells from newborns contributes significantly to their decreased filterability. (Pediatr Res 24: 433-437, 1988)
\end{abstract}

\section{Abbreviations}

DPH, 1,6-diphenyl-1,3,5-hexatriene

AS, 12-(9-anthroyl) stearic acid

THF, tetrahydrofuran

Hct, hematocrit

$\mathrm{Ca}_{c}$, intracellular calcium

$\mathrm{Ca}_{0}$, extracellular calcium

Red blood cells from human newborns, in addition to containing $\mathrm{HbF}$, differ from those of adults in having an increased mean cell volume $(1,2)$, decreased filterability (3), accelerated decline of cell deformability and membrane internalization during cell aging $(1,4)$, increased morphological abnormalities $(5$, 6 ), greater susceptibility to lipid peroxidation (7), altered enzyme levels and membrane transport and antigenic properties $(8,9)$, and a life span that is shortened by about one-third (10). Also,

Received June 19, 1987; accepted June 1, 1988.

Correspondence and reprint requests to Dr. Jeffrey C. Freedman, Department of Physiology, State University of New York Health Science Center, Syracuse, NY 13210.

Supported by NIH Grant GM28839 and by a grant-in-aid from the American Heart Association, Upstate New York Affiliate, Inc. Research submitted by L.M.C. in partial fulfillment of the requirement for the $\mathrm{Ph} . \mathrm{D}$. degree in the College of Graduate Studies of State University of New York Health Science Center at Syracuse, Syracuse, NY. ferritin-conjugated concanavalin $\mathrm{A}$ induces endocytosis in red cells from newborns, but not in those from adults (11). One hypothesis proposed to explain this difference in endocytosis was increased lipid fluidity of neonatal red cell membranes. However, fluorescence polarization studies of Kehry et al. (12) revealed no difference in the motional freedom of perylene in ghost membranes prepared from outdated adult red cells, as compared with ghosts from fresh neonatal red cells. Other studies suggest that it may be inappropriate to conclude from the data of Kehry et al. (12) that membrane lipid fluidity is the same for red cells from newborns and adults for the following two reasons: 1 ) the comparison was made with ghost membranes, yet DPH fluorescence polarization is increased in ghosts as compared with intact cells (13); and 2) the ghosts from adult cells were prepared from outdated blood, yet storage of blood reportedly alters membrane lipid fluidity (14). Our report describes experiments that reexamined membrane lipid fluidity of fresh intact red cells from human newborns and adults using the more sensitive fluorophore DPH. The results indicate that the motional freedom of both DPH and perylene is actually less in fresh, intact red cells from neonates as compared with adults. Experiments with elevated $\mathrm{Ca}_{\mathrm{c}}$ demonstrated conditions under which fluidity and filterability are independent and uncorrelated parameters. A preliminary account of some of these results was presented previously (15).

\section{MATERIALS AND METHODS}

Preparation of cells and ghosts. Fresh blood was drawn by venipuncture from normal adult donors, centrifuged at 13,800 $\times g$ at $4^{\circ} \mathrm{C}$ for $5 \mathrm{~min}$, and the buffy coat was aspirated. The red cells were then resuspended and washed three to four times in chilled cell wash medium containing (mM) $145 \mathrm{NaCl}, 5 \mathrm{KCl}$, and 5 HEPES (adjusted to $\mathrm{pH} 7.6$ at $23^{\circ} \mathrm{C}$ ). After the final wash, the cells were diluted to $50 \%$ Hct in cell wash medium and kept on ice for use on the same day. Blood from healthy term newborns was collected from the fetal vein of the placenta immediately after normal vaginal delivery without general anaesthetic, and the red cells were prepared using the same method as for blood from adults.

White ghosts were prepared (16) by hemolyzing the washed cells from adults or from newborn in 20:1 (vol/vol) ice cold 20 imosmol phosphate buffer $\left(\mathrm{pH} 8.0\right.$ at $25^{\circ} \mathrm{C}$ ) for $15 \mathrm{~min}$. The hemolysate was then centrifuged at $39,800 \times g$ at $4^{\circ} \mathrm{C}$ for $5 \mathrm{~min}$, the supernatant decanted, and the membranes washed repeatedly in the hypotonic buffer until white and devoid of $\mathrm{Hb}$. The final wash was in chilled cell wash medium with final resuspension to 1.5 to $2 \mathrm{mg}$ protein $/ \mathrm{ml}$, as determined by the method of Lowry et al. (17), using bovine serum albumin standards.

Membrane lipid fluidity. Following the method of Schachter et al. (18), we interpret the fluorescence anisotropy of lipid fluorophores as indicative of their motional freedom. The rate of rotation of a fluorophore, and hence the polarization of its emission, reflects viscous drag of the lipid environment in which 
the extrinsic probe is located. Decreased polarization or anisotropy may indicate a more fluid membrane, whereas increased polarization or anisotropy may indicate a more rigid environment. Because the rotational motion of DPH in red cell membranes is hindered (18-20), no attempt has been made to calculate microviscosities.

For fluorescence anisotropy measurements, a solution of $2 \mu \mathrm{M}$ DPH (232.3 g/mol, Aldrich Chem. Co., Milwaukee, WI) was prepared by diluting a stock solution of $2 \mathrm{mM} \mathrm{DPH}$ in fresh THF (Aldrich, stored under $\mathrm{N}_{2}$ to prevent peroxide formation) $1 / 1000$ into cell wash medium. The solution was stirred vigorously overnight in the dark at room temperature to evaporate the THF. Preliminary experiments indicated that use of aged THF, which forms peroxides during storage, resulted in formation of methemoglobin and in elevated values of DPH fluorescence anisotropy. From the $50 \%$ HCT suspension, red cells were added to the dye solution to $0.05 \% \mathrm{HCT}$, and the suspensions were then incubated $2 \mathrm{~h}$ in the dark at $37^{\circ} \mathrm{C}$ to enable dye uptake. The labeled cells were kept at $37^{\circ} \mathrm{C}$, and fluorescence anisotropy was measured three to five times at $37^{\circ} \mathrm{C}$ within the next hour. The fluorescence intensity and anisotropy of DPH increased during $1 \mathrm{~h}$ of labeling to a value that was then constant for up to $4 \mathrm{~h}$. At values of more than $0.25 \%$ Hct, the fluorescence of DPH at $427 \mathrm{~nm}$ is significantly absorbed by the Soret band of $\mathrm{Hb}$, centered at $420 \mathrm{~nm}$. A Hct of $0.05 \%$, corresponding to 0.8 $\mathrm{OD}$ at $365 \mathrm{~nm}$ for both adult and neonatal cells, minimized absorption as well as light scattering. DPH fluorescence anisotropy was constant between 0.01 and $0.10 \% \mathrm{Hct}$, indicating that errors from scattering depolarization are insignificant, and was also independent of DPH between 1 and $10 \mu \mathrm{M}$. Ghosts were added to a $2 \mu \mathrm{M}$ suspension of DPH in cell wash medium (which has been stirred overnight as for the intact cells) to a final concentration of $50 \mu \mathrm{g}$ protein $/ \mathrm{ml}$, and then incubated for $2 \mathrm{~h}$ at $37^{\circ} \mathrm{C}$ to incorporate the dye into the membranes. Fluorescence anisotropy of ghosts labeled with DPH was constant between 50 and $200 \mu \mathrm{g}$ protein $/ \mathrm{ml}$. The lower concentration was used to minimize light scattering.

With AS, perylene, or retinol the cells at $0.05 \%$ Hct, or the ghosts at $50 \mu \mathrm{g}$ protein $/ \mathrm{ml}$, were labeled by incubating for $1 \mathrm{~h}$ at $37^{\circ} \mathrm{C}$ in cell wash medium with dye. AS was added to $6 \mu \mathrm{M}$ from a stock solution of $2.5 \mathrm{mM}$ in $80 \% \mathrm{EtOH}$ with $10 \mathrm{mM}$ HEPES. Perylene was added to $5 \mu \mathrm{M}$ from a stock solution of 2 $\mathrm{mM}$ in $100 \% \mathrm{EtOH}$, whereas retinol was added to $1 \mu \mathrm{M}$ from a stock solution of $0.4 \mathrm{mM}$ in $100 \% \mathrm{EtOH}$.

At $0.05 \%$ Hct and at $50 \mu \mathrm{g}$ protein $/ \mathrm{ml}$ ghost concentration, the fluorescence of unlabeled membranes was less than $5 \%$ of the total DPH fluorescence, and the anisotropy of the scattered light closely approximated that of membranes labeled with DPH. Scatter corrections did not influence the DPH anisotropy measurements and therefore were not routinely made. For AS, retinol, and perylene the autofluorescence plus light scattering of unlabeled membranes was 5,7 , and $20 \%$, respectively, of the total signal from labeled membranes.

The fluorescence polarization and anisotropy of DPH were measured on a photon counting fluorimeter (model 8000S, SLMAminco, Urbana, IL) with excitation at $365 \mathrm{~nm}$ through a double monochromator with an 8- or 16-nm bandpass. A T-format was used, with one emission channel using a single monochromator set at $427 \mathrm{~nm}$ and with a $16 \mathrm{~nm}$ slit, and the other emission channel using a 3-mm thick cutoff filter (GG420, Schott Optical Glass, Inc., Duryea, PA) in series with a $50 \%$ neutral density filter (NG-11, Schott). The excitation and emission wavelengths for perylene were 404 and $447 \mathrm{~nm}$, for retinol were 334 and 482 $\mathrm{nm}$, and for AS were 367 and $450 \mathrm{~nm}$. Data were acquired for 5 $\mathrm{s}$ for each polarizer setting. The polarization, $\mathrm{P}$, is defined as $\mathrm{P}$ $=\left(I_{\|}-I_{\mid}\right) /\left(I_{\|}+I_{\mid}\right)$, and the anisotropy, $r$, is defined as $r=$ $\left(I_{\|}-I_{\mid}\right) /\left(I_{\|}+2 I_{\mid}\right)$, where $I_{\|}$and $I_{\mid}$are the fluorescence intensities of the vertically and horizontally polarized emissions when the sample is exited with vertically polarized light. The coefficient of variation for three to five repetitive determinations on a single sample with DPH averaged $6 \%$ for intact red cells and $2 \%$ for ghosts.

Filterability. Filterability was measured with a 5\% HCT suspension of red cells that had been washed three to four times and resuspended in the cell wash medium. The cell suspension was injected through a large bore needle attached to the upper reservoir of a Swinnex-25 filter unit (Millipore Corp., Bedford, MA) containing 25-mm diameter Whatman no. 42 filter paper (Thomas Scientific, Swedesboro, NJ) premoistened with cell wash medium. The injected sample filled an attached, vertically oriented 2-ml pipette up to the $2 \mathrm{ml}$ mark at a height of 23.5 $\mathrm{cm}$, and the unfiltered volume was noted every $15 \mathrm{~s}$ for up to 10 min. The volume filtered in $5 \mathrm{~min}$ was taken as the filterability.

Effect of calcium on fluidity and filterability. The Ca ionophore A23187 (Calbiochem, La Jolla, CA, $2.4 \mathrm{mM}$ stock solution in $100 \%$ ethanol) was added to a final concentration of $1 \mu \mathrm{M}$ to 3 $\mathrm{ml}$ of $0.05 \%$ HCT suspensions of DPH-labeled cells in cell wash medium containing 0-5 $\mathrm{mM} \mathrm{Ca}$. After $15 \mathrm{~min}$, DPH fluorescence anisotropy in the continuously stirring sample was determined. The fluorescence of $1 \mu \mathrm{M} \mathrm{A} 23187$ was less than $10 \%$ of the total sample fluorescence at the wavelengths used for DPH studies. Filterabilities were also determined $15 \mathrm{~min}$ after adding $1 \mu \mathrm{M} \mathrm{A} 23187$ to $0.05 \% \mathrm{HCT}$ suspensions of cells in cell wash medium containing $0-5 \mathrm{mM} \mathrm{Ca}_{0}$.

Statistics. Significance of differences for groups of unequal sizes was ascertained by means of Student's $t$ test.

\section{RESULTS}

Comparison of adult and newborn cells and ghosts. A scatter diagram showing the fluorescence anisotropy of DPH in fresh intact red cells and white ghosts from adults and newborns is shown in Figure 1. The mean DPH fluorescence anisotropy in red cells from newborns was $0.241 \pm 0.013(\mathrm{SD}, n=9), 16 \%$ more $(p<0.001)$ than the value of $0.208 \pm 0.010(n=17)$ for cells from adults. For ghosts membranes, DPH fluorescence anisotropy for newborns, $0.234 \pm 0.006(n=10)$, was only $5 \%$ more $(p<0.001)$ than the value for adults, $0.223 \pm 0.005(n=$ 26). The biological variation, expressed by the coefficient of variation of $5 \%$ for intact cells and $2 \%$ for ghosts, was comparable to the methodological variation of repetitive determinations on a single sample (see "Materials and methods"). Others have reported DPH anisotropies for ghosts from adults with values ranging from 0.192 to $0.219(14,19,21,22)$.

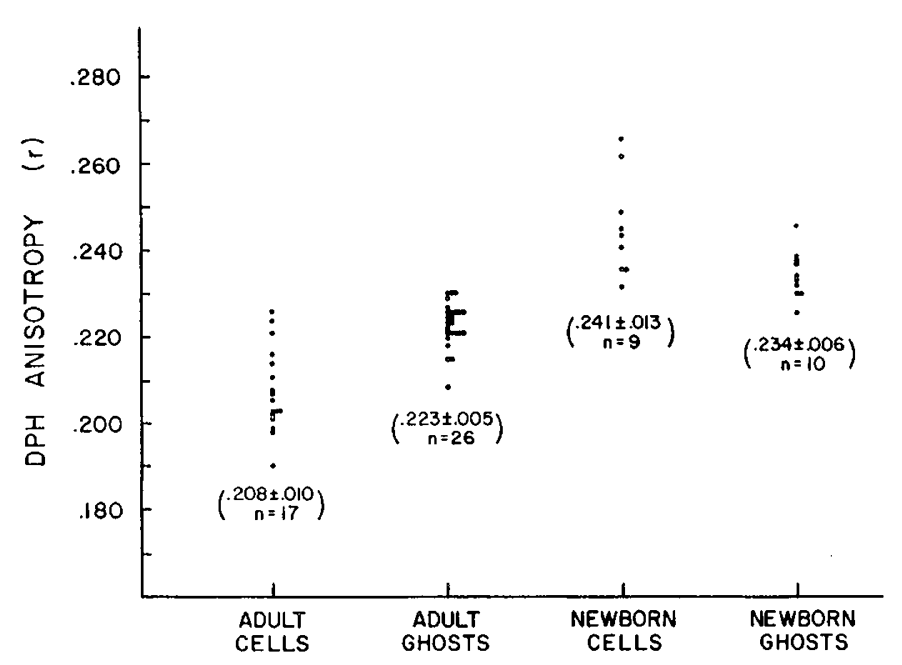

Fig. 1. Fluorescence anisotropy $(r)$ of DPH in fresh intact red blood cells and white ghost membranes from human adults and newborns. Each point represents the average of five determinations of a sample from the particular donor. Values in parentheses are means \pm SD for the different populations of donors. 
Table 1. Fluorescence anisotropy of four dyes used to compare membrane lipid fluidity of human red blood cells*

\begin{tabular}{|c|c|c|c|c|c|c|}
\hline \multirow[b]{2}{*}{ Probe } & \multicolumn{3}{|c|}{ Intact cells } & \multicolumn{3}{|c|}{ White ghosts } \\
\hline & Adult fresh & $\begin{array}{c}\text { Adult } \\
\text { outdated }\end{array}$ & Newborn & Adult fresh & $\begin{array}{c}\text { Adult } \\
\text { outdated }\end{array}$ & Newborn \\
\hline DPH & $\begin{array}{c}0.208 \pm 0.010 \\
(17)\end{array}$ & $\begin{array}{c}0.234 \pm 0.005 \\
(5)\end{array}$ & $\begin{array}{c}0.241 \pm 0.013 \\
(9)\end{array}$ & $\begin{array}{c}0.223 \pm 0.005 \\
(26)\end{array}$ & $\begin{array}{c}0.223 \pm 0.003 \\
(5)\end{array}$ & $\begin{array}{c}0.234 \pm 0.006 \\
(10)\end{array}$ \\
\hline Perylene & $\begin{array}{c}0.188 \pm 0.040 \\
(6)\end{array}$ & $\begin{array}{c}0.216 \pm 0.018 \\
(5)\end{array}$ & $\begin{array}{c}0.213 \pm 0.017 \\
(8)\end{array}$ & $\begin{array}{c}0.095 \pm 0.022 \\
(5)\end{array}$ & $\begin{array}{c}0.093 \pm 0.004 \\
(5)\end{array}$ & $\begin{array}{c}0.111 \pm 0.016 \\
(6)\end{array}$ \\
\hline AS & $\begin{array}{c}0.087 \pm 0.009 \\
(8)\end{array}$ & & $\begin{array}{c}0.089 \pm 0.009 \\
\text { (4) }\end{array}$ & $\begin{array}{c}0.114 \pm 0.008 \\
\text { (7) }\end{array}$ & & $\begin{array}{c}0.118 \pm 0.006 \\
(4)\end{array}$ \\
\hline Retinol & $\begin{array}{c}0.222 \pm 0.007 \\
(9)\end{array}$ & & $\begin{array}{c}0.221 \pm 0.007 \\
(5)\end{array}$ & $\begin{array}{c}0.216 \pm 0.004 \\
(5)\end{array}$ & & $\begin{array}{c}0.212 \pm 0.004 \\
(3)\end{array}$ \\
\hline
\end{tabular}

*Values are the means \pm SD for the number of donors shown in parentheses.

The mean DPH fluorescence anisotropy was significantly more $(p<0.001)$ in ghosts than in intact red cells from adults (Fig. 1; Table 2), consistent with a previous report by Aloni et al. (13) who prepared ghosts from fresh adult blood. In four paired experiments in which DPH fluorescence anisotropy was measured in cells and then in ghosts made from the same cells, the increase in ghosts was also significant $(p<0.05)$. In contrast, Schachter et al. (18) reported no difference in DPH fluorescence anisotropy between intact red cells and ghosts, but their study included the use of outdated bank blood. The results of Table 1 indicate that the fluorescence anisotropies of both DPH and perylene increase $(p<0.001)$ in outdated intact red cells. This increased DPH anisotropy with storage of intact cells and lack of difference in ghosts prepared from fresh and stored blood, contrasts with a decrease previously reported to occur with DPH in ghosts from outdated blood as compared with ghosts from fresh cells (14). The present data (Fig. 1; Table 1) suggest that changes during blood storage and during preparation of ghosts obscure differences in the fresh intact cells from adults and newborns.

Polar and nonpolar membrane fluidity probes. Both DPH and perylene are nonpolar molecules that are thought to partition into and monitor the properties of the hydrophobic core of the membrane. To probe the outer polar regions of the membranes, the polar fluorescent probes AS $(18)$ and retinol $(23,24)$ were used with red cells from newborns and adults. The fluorescence anisotropies of both AS and retinol were not significantly different in either the fresh intact cells or white ghosts from adults as compared to newborns (Table 1). The mean value of 0.114 for AS in ghosts from adults agrees well with the value of 0.120 reported by others $(25)$.

The fluorescence anisotropy of perylene was not significantly different in ghosts prepared from fresh or outdated red cells from adults, as compared to ghosts made from red cells of newborns (Table 1), which is in agreement with the data of Kehry et al. (12). In contrast, perylene exhibited significantly greater fluorescence anisotropy in the fresh intact cells from newborns as compared with fresh adult red cells $(p<0.05)$, again demonstrating the importance of examining fresh cells and confirming the difference detected with DPH. The large difference between the anisotropies of perylene in cells and ghosts (Table 1) may reflect the problems of its low fluorescence yield and the influence of light scattering that together make the results with perylene less reliable than those with DPH.

Effect of elevated $\mathrm{Ca}_{c}$ on fluidity and filterability. Elevated $\mathrm{Ca}_{c}$ decreases cellular deformability and filterability in red cells from adults (26). The results of Figure 2 confirm that red cells from newborns are less filterable $(p<0.001)$ than those from adults. Treating intact cells with $1 \mu \mathrm{M}$ Ca ionophore A23187 in the presence of up to $5 \mathrm{mM} \mathrm{Ca}$ occreased the filterability of adult cells $(p<0.001)$ but did not significantly affect the filterability

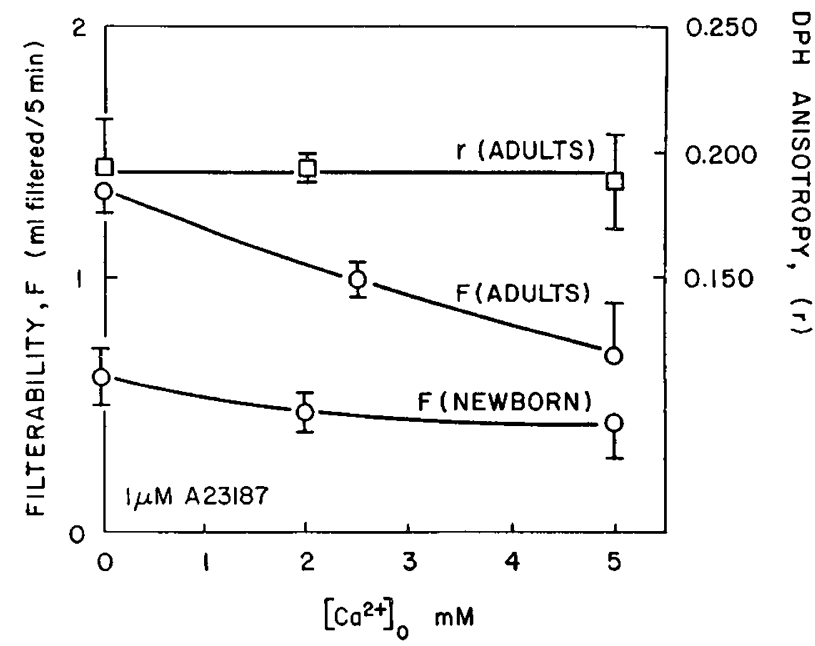

Fig. 2. The effect of $\mathrm{Ca}$ on DPH fluorescence anisotropy ( $r$, right ordinate) and on filterability ( $F$, left ordinate) of human red blood cells. Points represent means \pm SD for three donors.

of the cells from newborns. However, under identical experimental conditions, the fluorescence anisotropy of DPH remained constant in the adult cells (Fig. 2). Thus dramatic changes in filterability occur without detectable changes in the fluidity of the bulk lipids in the hydrophobic core of the membrane. Similar experiments using white ghosts from newborns and adults showed no change in the motional freedom of DPH, AS, or retinol as calcium was increased to $5 \mathrm{mM}$ (Table 2).

Effect of temperature on fluidity. As temperature was lowered from $37^{\circ} \mathrm{C}$ to $5^{\circ} \mathrm{C}$, DPH fluorescence anisotropy increased linearly in the cells or ghosts from either newborns or adults (Fig. 3 ), consistent with previous studies of the effect of temperature on membrane lipid fluidity in red cells $(13,25,27-29)$. DPH fluorescence anisotropy was greater at all temperatures between $5^{\circ} \mathrm{C}$ and $37^{\circ} \mathrm{C}$ in red cells from newborns, as compared to those from adults $(p<0.05)$, but the ghosts from the two cell types were similar over the entire temperature range. From Figure 3, it is evident that the fluidity of red cells from newborns at $37^{\circ} \mathrm{C}$ $\mathrm{r}_{\mathrm{DPH}}=0.260$, corresponds to the fluidity of cells from adults at $15^{\circ} \mathrm{C}$. Using temperature as a kind of ruler, DPH fluorescence anisotropy in fresh intact neonatal red cells is increased by an amount equivalent to that produced by cooling adult red cells by $22^{\circ} \mathrm{C}$.

\section{DISCUSSION}

The most important new result in our report is that DPH fluorescence anisotropy is significantly and substantially greater 
Table 2. Fluorescence anisotropy of $D P H, A S$, and retinol in white ghosts from adults and newborns in presence and absence of calcium*

\begin{tabular}{cccc}
\hline & \multirow{2}{*}{$\begin{array}{c}\text { Calcium } \\
\text { Probe }\end{array}$} & \multicolumn{2}{c}{ Fluorescence anisotropy } \\
\cline { 3 - 4 } DPH & 0 & $0.223 \pm 0.005(26)$ & $0.234 \pm 0.006(10)$ \\
& 0.5 & $0.227 \pm 0.003(3)$ & $0.232 \pm 0.004(3)$ \\
& 5.0 & $0.226 \pm 0.003(3)$ & $0.236 \pm 0.006(3)$ \\
& & & \\
AS & 0 & $0.114 \pm 0.008(5)$ & $0.118 \pm 0.008(3)$ \\
& 0.5 & $0.119 \pm 0.009(6)$ & $0.114 \pm 0.009(3)$ \\
& 5.0 & $0.115 \pm 0.007(3)$ & $0.114 \pm 0.002(3)$ \\
Retinol & 0 & $0.216 \pm 0.004(5)$ & $0.212 \pm 0.004(3)$ \\
& 0.5 & $0.225 \pm 0.014(6)$ & $0.207 \pm 0.004(3)$ \\
& 5.0 & $0.215 \pm 0.007(3)$ & $0.212 \pm 0.009(3)$ \\
\hline
\end{tabular}

* Values are means \pm SD for number of donors shown in parentheses.

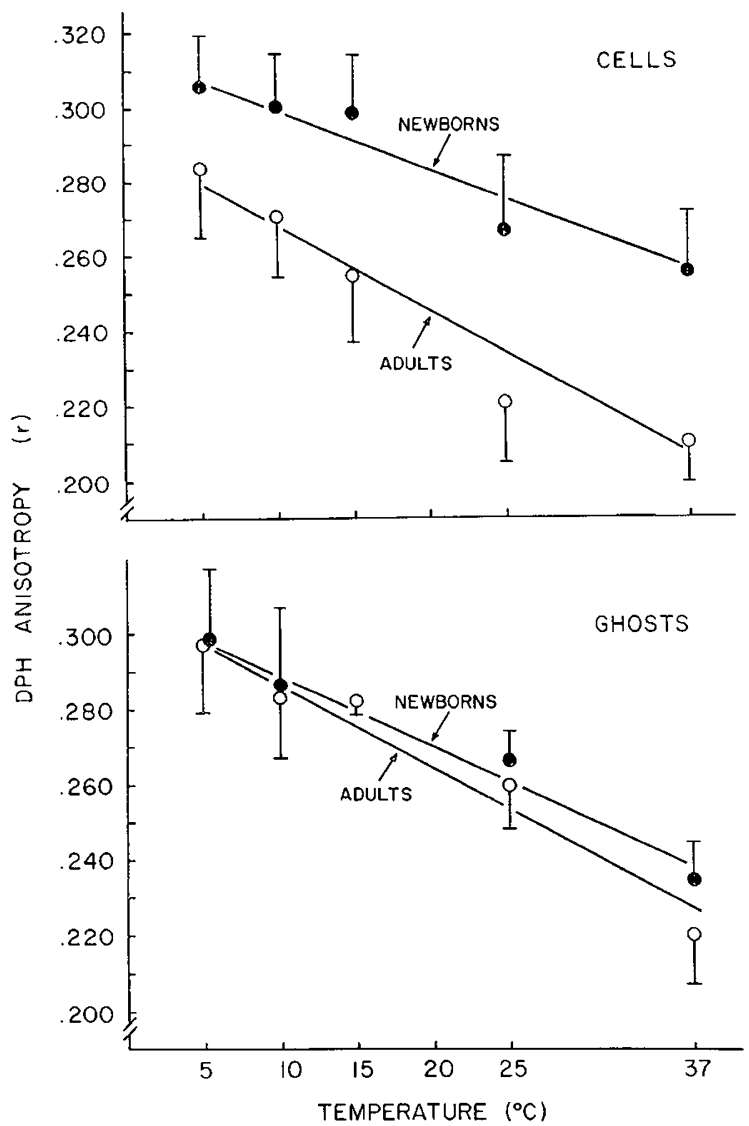

Fig. 3. The effect of temperature on DPH fluorescence anisotropy in fresh intact cells (top panel) and white ghosts (bottom panel) from newborns (closed circles) and adults (open circles). Points represent means \pm SD for five donors.

in the membranes of fresh intact red cells from human newborns as compared to those from adults, but the values are closer in the ghost membranes of both cell types (Fig. 1; Table 1). The motional freedom of perylene is also greater in red cells from adults than from newborns, and similar in ghost membranes from the two types of red cells, implying that the main result is independent of the specific probe used. The fluorescence anisotropies of the more polar probes, AS and retinol, are similar in both cell types (Table 1). These observations suggest that probes in the hydrophobic core of the intact red cell membranes from newborns have less motional freedom than in the core of red cell membranes from adults, but the more polar regions of the two membranes are similar.

In a study of lipid lateral mobility using the technique of fluorescence photobleaching recovery, Bloom and Webb (30) found that the diffusion coefficient of the cyanine dye diI- $\mathrm{C}_{18}(5)$ was reduced by $30 \%$ in prenatal murine red cells, and was reduced by 2 -fold in ghosts from human red cells, in qualitative agreement with our results. Although lipid lateral mobility reflects both hydrocarbon chain disorder and molecular packing in the bilayer, DPH fluorescence anisotropy is primarily sensitive to chain disorder (30).

Red cell membranes from human newborns, as compared to those from adults, are known to contain slightly higher ratios of sphingomyelin to phosphatidylcholine, free cholesterol to phospholipid, and saturated to unsaturated fatty acids $(31,32)$. These differences in lipid composition would be qualitatively consistent with a less fluid hydrophobic membrane core in cells from newborns with no difference in the outer polar regions of the bilayer. However, studies of cholesterol-enriched red cells (28) indicate that an increase in DPH fluorescence anisotropy of the magnitude found for neonatal red cells would require a 2 -fold increase in the ratio of cholesterol to phosopholipid, much greater than the $15 \%$ increase that actually exists (32). Similarly, the slight increase in the ratio of sphingomyelin to phosphatidylcholine from 0.84 in adults to 0.94 in neonates $(31,32)$ also seems inadequate to account for the increase in DPH fluorescence anisotropy. In patients with spur-cell anemia the red cell sphingomyelin to phosphatidylcholine ratio is elevated to values near $1.5(27)$, much higher than in neonates, yet DPH fluorescence anisotropy is less than we find for neonatal red cells (Fig. 1; Table 1). The increased proportion of saturated fatty acids, from $38 \%$ in adults to $43 \%$ in newborns $(31,32)$, is another possible explanation for the decreased motional freedom of DPH and perylene in neonatal red cells. The most prominent change in red cell unsaturated fatty acids during the first month of life is a progressive increase of linoleic acid (18:2) and a decrease of arachidonic acid (20:4), reflecting changes in the lipid fractions of plasma (33). However, no clear relationship between fatty acid composition and membrane lipid fluidity of red cells has been demonstrated (34). Moreover, the unsaturation index, or average number of double bonds per mole or gram fatty acids, is 1.47 in red cells from newborns, very similar to the unsaturation index of 1.55 for adult red cell phospholipid fatty acids (calculated from data in Refs. 31-32).

If known differences in lipid composition cannot explain the decreased motional freedom of probes in neonatal red cell membranes, then another possible explanation might relate to their reduced vitamin $\mathrm{E}$ content (35). Peroxidation of ghost membranes with phenylhydrazine, leading to accumulation of malonyldialdehyde, does elevate DPH fluorescence anisotropy (36). In support of this hypothesis, elevated malonyldialdehyde levels have recently been reported for neonatal red cells (37).

The data in our report for red cell ghosts do agree with those of Kehry et al. (12) in that little or no difference was found in the fluidity of ghost membranes from newborns and adults, as determined by DPH and perylene fluorescence anisotropies (Table 1). Preparation of ghosts from red cells of adults alters the lipids such that DPH has less motional freedom than in cells (Fig. 1; Table 1), consistent with a previous report by Aloni et al. (13). Schachter et al. (18) reported an increase in the excited state lifetime of DPH from $6.0 \mathrm{~ns}$ in intact red cells to $9.8 \mathrm{~ns}$ in ghosts, but this change is in the wrong direction to account for the increased DPH fluorescence anisotropy in ghosts. During preparation of ghosts in the presence of $5-10 \mu \mathrm{M}$ calcium, phospholipid asymmetry is reportedly abolished (38), although total lipid content is conserved (16). If the outer hemileaflet is more fluid than the inner (39), and if DPH preferentially monitors the outer leaflet fluidity $(18,39)$, then loss of phospholipid asymmetry might contribute to the increased DPH fluorescence anisotropy in ghosts. 
Unlike cells and ghosts from adults, neonatal red cells and ghosts showed similar DPH fluorescence anisotropies (Fig. 1; Table 1). If a loss of phospholipid asymmetry contributes to the elevated DPH fluorescence anisotropy in adult red cell ghosts, then this property might also be relevant for intact neonatal red cells. Partial alteration of phospholipid asymmetry has recently been reported for red cells from neonates (37).

Inasmuch as red cells from newborns have a shortened lifespan, and thus a younger mean cell age than red cells from adults, it is also important to consider how fluidity changes during cell maturation. The fluorescence anisotropy of perylene was reported to be decreased in reticulocyte-rich blood obtained from phenylhydrazine-treated rabbits (40). When these cells were separated according to age by density centrifugation, old cells being more dense, motional freedom decreased with increasing density. This change is in the wrong direction to explain the difference in red cells from human newborns and adults. It is also of interest that the changes noted during maturation of intact rabbit red cells were not evident in ghosts prepared from the cells (40).

Although fluorescence anisotropy studies indicate less motional freedom in red cell membranes from newborns than from adults, it is unlikely that this difference contributes significantly to the decreased filterability of neonatal red cells. Others have shown that the decreased filterability of neonatal red cells can be attributed to their large size and to the increased proportion of rigid cells (3). A previous report with ghosts from adults also showed that up to $10 \mathrm{mM} \mathrm{Ca}$ did not change membrane lipid fluidity, as monitored with DPH (13). In contrast, electron spin resonance studies using nitroxide spin-labeled fatty acid (41) and phospholipids (42) reported increased fluidity upon exposure to $1 \mathrm{mM}$ Ca during hemolysis (41), or after 5-min exposure to 10 $\mu \mathrm{M} \mathrm{Ca}{ }_{o}$ with A23187-treated intact cells (42). The result that elevated $\mathrm{Ca}_{c}$ decreases filterability without affecting the motional freedom of DPH in intact cells (Fig. 2) provides another example of the independence of membrane lipid fluidity and viscoelastic properties, and agrees with a similar conclusion from studies of red cells with modified cholesterol contents (43).

In summary, the substantially increased DPH fluorescence anisotropy in fresh intact red blood cells from newborns as compared with adults could reflect increased lipid oxidation or decreased phospholipid asymmetry. The molecular basis for this observation and the possible relationship of decreased membrane lipid fluidity to other functional properties of neonatal red cells, including their shortened lifespans, remains to be determined.

\section{REFERENCES}

1. Linderkamp O, Wu PYK, Meiselman HJ 1982 Deformability of density separated red blood cells in normal infants and adults. Pediatr Res 16:964968

2. Linderkamp O, Wu PYK, Meiselman HJ 1983 Geometry of neonatal and adult red blood cells. Pediatr Res 17:250-253

3. Linderkamp O, Hammer BJ, Miller R 1986 Filterability of erythrocytes and whole blood in preterm and full-term neonates and adults. Pediatr Res 20:1269-1273

4. Matovcik LM, Chiu D, Lubin B, Mentzer WC, Lane PA, Mohandas N, Shrier SL 1986 The aging process of human neonatal erythrocytes. Pediatr Res 20:1091-1096

5. Zipursky A, Brown E, Palko J, Brown EJ 1983 The erythrocyte differential count in newborn infants. Am J Pediatr Hematol Oncol 5:5-51

6. Coulombel L, Tchernia G, Feo C, Mohandas N 1982 Echinocytic sensitivity and deformability of human newborn red cells. Biol Neonate 42:284-290

7. Lubin B, Oski FA 1972 Red cell metabolism in the newborn infant. VI. Irreversible oxidant-induced injury. J Pediatr 81:698-704

8. Stockman JA, Oski FA 1978 Erythrocytes of the human neonate. Curr Topics Hematol 1:193-232

9. Matovcik LM, Mentzer WC 1985 The membrane of the human neonatal red cell. Clin Haematol 14:203-221

10. Pearson HA 1967 Life-span of the fetal red blood cell. J Pediatr 70:166-171

11. Schekman R, Singer SJ 1976 Clustering and endocytosis of membrane receptors can be induced in mature erythrocytes of neonatal but not adult humans. Proc Natl Acad Sci USA 73:4075-4079
12. Kehry M, Yguerabide J, Singer SJ 1977 Fluidity in the membranes of adult and neonatal human erythrocytes. Science 195:486-487

13. Aloni B, Shinitzky M, Livne A 1974 Dynamics of erythrocytes lipids in intact cells, in ghost membranes and in liposomes. Biochim Biophys Acta 348:438441

14. Jarolim P, Mircevova L 1982 Changes in fluidity of erythrocyte membranes after storage of erythrocytes and regeneration of cellular ATP levels. Biochim Biophys Acta 688:460-464

15. Crespo LM, Bifano EM, Freedman JC 1984 Membrane lipid fluidity and filterability of human red blood cells from adults and newborns. Prog Clin Biol Res 165:525-526(abstr)

16. Dodge JT, Mitchell C, Hanahan DJ 1963 The preparation and chemical characteristics of hemoglobin-free ghosts of human erythrocytes. Arch Biochem Biophys 100:119-130

17. Lowry OH, Rosebrough NJ, Faar AL, Randall RJ 1951 Protein measurement with the Folin phenol reagent. J Biol Chem 193:265-275

18. Schachter D, Cogan U, Abbott RE 1982 Asymmetry of lipid dynamics in human erythrocyte membranes studied with permeant fluorophores. Biochemistry 21:2146-2150

19. Kinosita K, Kataoka R, Kimura Y, Gotoh O, Ikegami A 1981 Dynamic structure of biological membranes as probed by 1,6-diphenyl-1,3,5-hexatriene: a nanosecond fluorescence depolarization study. Biochem 20:4270 4277

20. Kinosita K, Kawato S, Ikegami A 1984 Dynamic structure of biological and model membranes: analysis of optical anisotropy decay measurements. Adv Biophys 17:147-203

21. Owen JS, Bruckdorfer KR, Day RC, McIntyre N 1982 Decreased erythrocyte membrane fluidity and altered lipid composition in human liver disease. J Lipid Res 23:124-132

22. Rice-Evans C, Hochstein P 1981 Alterations in erythrocyte membrane fluidity by phenylhydrazine-induced peroxidation of lipids. Biochem Biophys Res Commun 100:1537-1542

23. Schachter D, Shinitzky M 1977 Fluorescence polarization studies of rat intestinal microvillus membranes. J Clin Invest 59:536-548

24. Radda GK, Smith DS 1970 Retinol: a fluorescent probe for membrane lipids FEBS Lett 9:287-289

25. Vanderkooi J, Fishkoff S, Chance B, Cooper RA 1974 Fluorescent probe analysis of the lipid architecture of natural and cholesterol rich membranes. Biochemistry 13:1589-1595

26. Weed RI, Lacelle PL, Merrill EW 1969 Metabolic dependence of red cel deformability. J Clin Invest 48:795-809

27. Cooper RA, Durocher JR, Leslie MH 1977 Decreased fluidity of red cell membrane lipids in abetalipoproteinemia. J Clin Invest 60:115-121

28. Cooper RA, Leslie MH, Fischkoff S, Shinitzky M, Shattil SJ 1978 Factors influencing the lipid composition and fluidity of red cell membranes in vitro: production of red cells possessing more than two cholesterols per phospholipid. Biochemistry 17:327-331

29. Rudy B, Gitler C 1972 Microviscosity of the cell membrane. Biochim Biophys Acta 288:231-236

30. Bloom JA, Webb WW 1983 Lipid diffusibility in the intact erythrocyte membrane. Biophys J 42:295-305

31. Crowley J, Ways P, Jones JW 1965 Human fetal erythrocyte and plasma lipids J Clin Invest 44:989-998

32. Neerhout RC 1968 Erythrocyte lipids in the neonate. Pediatr Res 2:172-178

33. Ciccoli L, Hayek D, Bracci K 1981 Fatty acid pattern of the erythrocyte lipids and plasma vitamin $E$ in the first days of life. Biol Neonate 40:187-195

34. Popp-Snijders C, Schouten JA, Van Blitterswijk WJ, van der Veen EA 1986 Changes in membrane lipid composition of human erythrocytes after dietary supplementation of $(n-3)$ polyunsaturated fatty acids. Maintenance of membrane fluidity. Biochim Biophys Acta 854:31-37

35. Oski FA, Barness LA 1967 Vitamin E deficiency: a previously unrecognized cause of hemolytic anemia in the premature infant. J Pediatr 70:211-220

36. Rice-Evans C, Hochstein P 1981 Alterations in erythrocyte membrane fluidity by phenylhydrazine-induced peroxidation of lipids. Biochem Biophys Res Commun 100:1537-1542

37. Jain SK 1987 Elevated malonyldialdehyde levels, altered membrane lipid asymmetry, and hypercoagulability of erythrocytes from newborn infants. Biomed Biochim Acta 46:S21-S25

38. Williamson P, Algarin L, Bateman J, Choe H-R, Schlegel RA 1985 Phospholipid asymmetry in human erythrocyte ghosts. J Cell Physiol 123:209-214

39. Schachter D, Abbot RE, Cogan U, Flamm M 1983 Lipid fluidities of the individual hemileaflets of human erythrocyte membranes. Ann NY Acad Sci 414:19-28

40. Katsumata Y, Tanaka F, Haighara M, Yagi K 1977 Changes in membrane fluidity of erythrocytes during cell maturation. Biochem Biophys Res Commun 78:609-614

41. Adams D, Markes ME, Leivo WJ, Carraway KL 1976 Electron spin resonance analysis of irreversible changes induced by calcium perturbation of erythrocyte membranes. Biochim Biophys Acta 426:38-45

42. Yamada S, Ohriski S 1983 Erythrocyte membrane fluidity change induced by intracellular delivery of $\mathrm{Ca} 2+$. Acta Haematol Jpn 46:1406-1413

43. Chabanel A, Flamm M, Sung KLP, Lee MM, Schachter D, Chien S 1983 Influence of cholesterol content on red cell membrane viscoelasticity and fluidity. Biophys J 44:171-176 